medRxiv preprint doi: https://doi.org/10.1101/2020.07.29.20163469; this version posted July 30, 2020. The copyright holder for this preprint

(which was not certified by peer review) is the author/funder, who has granted medRxiv a license to display the preprint in perpetuity.

1 Deep skin dysbiosis in vitiligo patients: link with mitochondrial and immune changes

2

3 Authors: Hanene Bzioueche $1^{*}$, Kotryna Simonyté Sjödin2*, Christina E West2, Abdallah

4 Khemis 3 , Stéphane Rocchi 1 , Thierry Passeron $1,3+\S$ and Meri K Tulic 1 †§

5

6 Affiliations:

7 1Université Côte d'Azur, INSERM U1065, Centre Méditerranéen de Médecine Moléculaire

8 (C3M), Nice, France

92 Department of Clinical Sciences, Pediatrics, Umeå University, Umeå, Sweden

10 3 Côte d'Azur University. Department of Dermatology, University Hospital of Nice, France

11

12

* These two authors contributed equally to this work, + equal senior-author contributions $\S$ corresponding authors

\title{
$\S$ Correspondences:
}

17 Dr Meri K Tulic

18 INSERM U1065, C3M

19150 route de Ginestiere 06200 Nice, France

20 Email: meri.tulic@unice.fr

Pr. Thierry Passeron

23 Department of Dermatology, Archet 2 Hospital.

24150 route de Ginestiere 06200 Nice, France

25 Email: passeron@unice.fr

Running Title: Gut and skin dysbiosis in vitiligo 
medRxiv preprint doi: https://doi.org/10.1101/2020.07.29.20163469; this version posted July 30, 2020. The copyright holder for this preprint (which was not certified by peer review) is the author/funder, who has granted medRxiv a license to display the preprint in perpetuity.

\section{ABSTRACT}

Rationale: Vitiligo is an autoimmune-disease characterized by patchy, white skin due to melanocyte loss. Commensal cutaneous or gut dysbiosis have been linked to various dermatological disorders. Here, we studied skin and gut microbiota of vitiligo patients compared to healthy controls. Methods: We recruited 20 subjects and obtained swabs and biopsies from lesional and non-lesional skin, stool and blood from each individual (total 100 samples). Results: We detected reduced richness and distribution of microbiota in stool of vitiligo subjects compared to controls $(P<0.01)$. Skin swabs had greater alpha-diversity than skin biopsies $(\mathrm{P}<0.001)$, however only trends were seen between groups when examining microbiota at the skin surface. This was in contrast to sampling deeper layers of skin from the same patients which showed decreased richness and distribution of species $(P<0.01)$ but greater phylogenetic diversity $(P<0.01)$ in lesional compared to non-lesional sites. Biopsy microbiota from the lesional skin had distinct microbiota composition which was depleted of protective Bifidobacterium and enriched in Terenicutes, Streptococcus, Mycoplasma and mitochondrial DNA $(\mathrm{P}<0.001)$; the latter was linked with increased innate immunity and stress markers in the blood of the same patients $(P<0.05)$. Conclusion: These data describe vitiligospecific cutaneous and gut microbiota and, for the first time in humans, a link between mitochondrial alteration, innate immunity and skin microbiota.

52

53 Keywords: skin dysbiosis, microbiota, vitiligo, immunity, melanocytes 
medRxiv preprint doi: https://doi.org/10.1101/2020.07.29.20163469; this version posted July 30, 2020. The copyright holder for this preprint (which was not certified by peer review) is the author/funder, who has granted medRxiv a license to display the preprint in perpetuity.

\section{INTRODUCTION}

Vitiligo is characterized by an acquired loss of melanocytes in the skin and sometimes in the hair follicles. It is now well demonstrated that CD8+ T cells attracted in the epidermis are responsible for the melanocytic loss. Genome-wide association studies (GWAS) identified over 50 vitiligo susceptibility loci involved in melanogenesis and immunity in vitiligo patients [1]. However, these genetic studies and a delay in vitiligo age-of-onset over the past 30 years emphasize the key role of environmental factors in triggering vitiligo [2]. We recently demonstrated that vitiligo patients have an increased number of natural killer (NK) and innate immune cells (ILC1) in their non-lesional skin and their blood, and that those innate cells have a greater response to stress, producing higher amount of IFN $\gamma$ leading to the production of chemokine (C-X-C motif) ligand 9 (CXCL9), CXCL10 and CXCL11 by both keratinocytes and melanocytes and to a CXCR3B-induced apoptosis in melanocytes [3]. We demonstrated that these early events which lead to CD8+ $\mathrm{T}$ cell-mediated adaptative response against melanocytes can be triggered by endogeneous or exogeneous stress, namely damage and pattern-associated molecular patterns (DAMPs and PAMPs, respectively). Bacteria are among the top producers of PAMPs and could participate in activation of the innate immune response in vitiligo. Interestingly, gut dysbiosis has been reported in several auto-immune disorders. Although less reported, skin dysbiosis is also observed in some dermatoses, such as acne, psoriasis and atopic dermatitis [4-6]. Most of these studies assessed the superficial microbiome using swabs. However, recent data emphasized the differences in the microbiome between the surface and the deeper part of the skin using biopsy samples $[7,8]$. Surprisingly, data on the microbiome in vitiligo patients remains sparse. To date, there exists only one study suggesting dysbiosis in vitiligo skin [9], however the authors only assessed the superficial skin microbiota using swabs and compared lesional to non-lesional vitiligo skin without including healthy controls. A more recent study in a mouse model of vitiligo has shown that antibioticinduced depletion of Bacteroides-dominated population in the gut may induce depigmentation in the skin suggesting a possible link between gut and skin compartments [10]. In the present 
medRxiv preprint doi: https://doi.org/10.1101/2020.07.29.20163469; this version posted July 30, 2020. The copyright holder for this preprint (which was not certified by peer review) is the author/funder, who has granted medRxiv a license to display the preprint in perpetuity. All rights reserved. No reuse allowed without permission.

82 study, we compared for the first time, the microbiota of gut, superficial and deeper parts of

83 lesional and non-lesional skin of vitiligo patients and compared these results to sample and

84 site matched healthy controls. We found gut dysbiosis with a reduced Bacteroides population

85 in vitiligo patients. We also report marked differences of the microbiota using swabs and skin

86 biopsies. Finally, we report significant variation in microbiota diversity and quality in the deeper regions of lesional vitiligo skin and these changes to be associated with mitochondrial damage

88 and changes in skin immunity.

89 
medRxiv preprint doi: https://doi.org/10.1101/2020.07.29.20163469; this version posted July 30, 2020. The copyright holder for this preprint (which was not certified by peer review) is the author/funder, who has granted medRxiv a license to display the preprint in perpetuity.

\section{RESULTS}

Vitiligo disease is associated with lower $\alpha$-diversity and increased Firmicutes/Bacteroidetes fraction in the gut

First, we set out to examine if we could detect differences in microbial composition and diversity in the gut of patients with vitiligo skin disease $(n=10)$ compared to healthy controls $(n=10)$. Here we show lower gut microbial a-diversity in vitiligo patiens compared to healthy controls (for observed OTUs $\mathrm{P}=0.005$; Shannon diversity index $\mathrm{P}=0.115$; and Faith's Phylogenetic Diversity $\mathrm{H}=5.851, \mathrm{P}=0.006$ ) (Figure $1 \mathrm{~A}$ ). $\beta$-diversity did not differ between the groups. We found trends for higher bacterial relative abundance $(\mathrm{RA})$ of Firmicutes $(\mathrm{P}=0.09)$ and lower Bacteroidetes $(\mathrm{P}=0.08)$ in the stools of vitiligo subjects compared to healthy controls (Figure 1B and Supplementary Table 1) which is likely to be a result of reduced Bacteroides (Figure $1 \mathrm{C}$ and Supplementary Table 2). The ratio between Firmicutes and Bacteroidetes (F/B) was $8.5 \pm 1.2$ (mean \pm SEM) controls and $18.5 \pm 2.6$ for vitiligo patients $(P<0.01)$.

\section{Significant microbial dissimilarity between swabs and biopsies}

To examine if there are differences in microbial composition and diversity in the skin of vitiligo patients compared to healthy skin, we studied microbiota extracted from paired skin swabs and skin biopsies from the same subject as well as collected samples from the patient's lesional and non-lesional skin sites. We compared microbial communities $\alpha$ - and $\beta$-diversity between swab or biopsy samples from control, lesional $(L)$ and non-lesional $(N L)$ sites $(n=30$ swab and $n=30$ biopsy). Observed OTUs and Shannon diversity index were higher in swabs compared to biopsies $(\mathrm{P}<0.001$ for both; Figure $2 \mathrm{~A})$, whereas Faith's PD was higher in biopsies $(P<0.001$; Figure 2A), the latter suggesting higher phylogenetic richness in biopsies compared to swabs. These results suggest richness and distribution of bacteria ( $\alpha$-diversity) differs in relation to the sampling method. Furthermore, our results demonstrate distinct and significant

118 Enterococcus in biopsies compared to swabs, whereas Staphylococcus, Paracoccus, Kocuria, 
medRxiv preprint doi: https://doi.org/10.1101/2020.07.29.20163469; this version posted July 30, 2020. The copyright holder for this preprint (which was not certified by peer review) is the author/funder, who has granted medRxiv a license to display the preprint in perpetuity. All rights reserved. No reuse allowed without permission.

Micrococcus and Anaerococcus were more abundant in the skin swabs $(p<0.05$ for all comparisons; Figure 2C). In the swabs, Staphylococcus was the most abundant genus making up $>30 \%$ of all bacteria while in the biopsies, Bifidobacterium was the most common, making up almost $60 \%$ of the total bacterial load. Taken together, these results demonstrate a marked difference in the skin microbiome when analyzed using swab versus biopsy sampling and there are several bacterial genera that correlates strongly and significantly with the sample collection method or the depth of microbiota sampling.

\section{Depletion of Staphylococcus and enrichment of Proteobacteria in lesional swabs of vitiligo} patients

Swab samples from NL and $L$ vitiligo skin had a significantly higher $\alpha$-diversity compared to healthy control swabs $(\mathrm{P}<0.05)($ Figure $3 \mathrm{~A})$. There was no difference in $\alpha$-diversity between $N L$ and $L$ skin samples (Figure 3A). We found no significant differences in $\beta$-diversity between healthy, NL and $\mathrm{L}$ skin swab samples. We observed decreased Firmicutes in $\mathrm{L}$ compared to NL sites $(p<0.01)$ (Figure 3B and Supplementary Table 3); most likely due to decreased Staphylococcus at this site $(\mathrm{p}<0.02)$ (Figure $3 \mathrm{C}$ and Supplementary Table 4). Examining the bacterial composition of swab microbiota at the genus level, we show that greater than half of taxonomic assignments on skin surface belong to 5 major genera: Staphylococcus, Corynebacterium, Cutibacterium (formerly Propionibacterium), Kocuria and Paracoccus (Figure $3 \mathrm{C})$. We found a trend for lower Cutibacterium in L compared to NL swabs $(p=0.057)$ (Figure 3C) which may have important implications in vitiligo as the loss of Cutibacterium diversity triggers activation of the innate immune system [11]. We have also seen trends for increased Proteobacteria ( $p=0.08$ ) phylum in $L$ compared to $N L$ swabs (Figure $3 B$ ). As Proteobacteria contains many well-known human pathogens and is related with disbalance and inflammation [12], we investigated this phylum in more detail. We have shown a diseasedependent increase in presence of Gammaproteobacteria, that is relative abundance in $\mathrm{L}>\mathrm{NL}>\mathrm{C}$ swabs and disease-dependent decreased in Alphaproteobacteria $(\mathrm{L}<\mathrm{NL}<\mathrm{C})$ $(P=0.046)$ (Supplementary Figure 1A and Supplementary Table 5). Lesional skin enrichment 
medRxiv preprint doi: https://doi.org/10.1101/2020.07.29.20163469; this version posted July 30, 2020. The copyright holder for this preprint (which was not certified by peer review) is the author/funder, who has granted medRxiv a license to display the preprint in perpetuity. All rights reserved. No reuse allowed without permission.

147 with Gammaproteobacteria has also been shown in the only other study to date in vitiligo 148 subjects [9]. We have shown trends for increased Paracoccus $(p=0.09)$ and Acinetobacter $149(p=0.08)$ in vitiligo swabs compared to control swabs (Supplementary Figure 1B). Differences 150 in Haematobacter were not statistically different due to patient variability.

Biopsy microbiota in lesional skin have distinct composition and are associated with

153 mitochondrial damage

154 In contrast to the swabs, microbial community $\beta$-diversity in L skin biopsies differed significantly 155 compared to NL skin biopsies or healthy controls $(p<0.001)$ (Figure $4 A$ ) and had the most 156 distinct microbiota compared to all other groups (Supplementary Figure 2). We saw a decrease 157 in species richness and distribution (Shannon index, $\mathrm{P}=0.006$ ) but increase in phylogenetic 158 diversity (Faith's $P D, P=0.003$ ) in biopsies from $L$ compared to NL skin, whereas Shannon 159 index was higher in NL skin compared to controls $(P<0.01)$ (Figure 4B). The taxa bar plots 160 suggest decreased Actinobacteria $(p=0.09)$ and increased Firmicutes $(p=0.08)$ in $L$ compared 161 to NL or control biopsies (Figure 4C and Supplementary Table 6). In our cohort, the largest 162 difference was the increase in Tenericutes $(\mathrm{P}<0.001$ for control versus $\mathrm{NL}$ and $\mathrm{P}<0.02$ for $\mathrm{NL}$ 163 versus $L)$ and mitochondrial DNA ( $p<0.007)$ exclusively in biopsies from $7 / 10$ lesional skin 164 samples whereby 3 out of the 10 samples looked like NL skin (Figure 4C).

166 In the skin biopsies, greater than half of taxonomic assignments belong to 5 major genera (3 167 overlapping with the swabs): Bifidobacterium, Escherichia-Shigella, Staphylococcus, 168 Cutibacterium and Parabacteroides (Figure 4D and Supplementary Table 7). The heat map 169 illustrates the top 20 most differentially expressed bacterial taxa between the three groups at 170 the individual level (Supplementary Figure 3). Pair-wise analysis for differential abundance 171 between NL vitiligo biopsies and control biopsies have shown Staphylococcus and

172 Cutibacterium to be depleted in NL biopsies $(p=0.07)$; the same two genera that were depleted 173 on the surface of L skin. In contrast, Enterococcus, Mycoplasma, Veillonella, Intestinibacter, 174 Bacteroides, Escherichia-Shigella, Parabacteroides, Bifidobacterium, and Streptococcus were 
medRxiv preprint doi: https://doi.org/10.1101/2020.07.29.20163469; this version posted July 30, 2020. The copyright holder for this preprint (which was not certified by peer review) is the author/funder, who has granted medRxiv a license to display the preprint in perpetuity.

175 enriched at NL sites (all $p<0.007$ ) (Supplementary Figure 3). Comparisons between $L$ and NL

176 biopsies have shown L skin to be further enriched for Streptococcus as well as Proteobacteria

177 including Gemella, Raistonia and Undibacterium (all $p<0.05$ ) with a large and specific increase

178 in Mycoplasma and Mitochondrial DNA (Figure 4D). In contrast, Bifidobacterium, Escherichia-

179 Shigella, Parabacteroides and Enterococcus were significantly depleted taxa in biopsies from

$180 \mathrm{~L}$ compared to NL skin and compared to healthy biopsies (all $p<0.05$ ). Bifidobacterium was

181 completely depleted in $7 / 10 \mathrm{~L}$ biopsies when compared to their matched NL sites in which

182 Bifidobacterium makes up almost $60 \%$ of the total bacterial genus (Figure 4D).

183

184 Finally, we further investigated the differences between the first 3 patients who didn't have an increase in mitochondrial DNA in their skin biopsy to the remaining 7 patients who did. Interestingly, these 3 patients had a similar microbiome to non-lesional samples, that is, low

187 abundance of Tenericutes and Firmicutes with predominant presence of Actinobacteria (Figure 188 4C). The difference between these 2 sub-groups of patients could not be explained by sex, 189 age, location of the biopsies, disease activity or disease duration. To further investigate if these 190 changes in the skin could activate the innate immune response, we measured the levels of 191 IFN $\gamma$ and chemokines CXCL9 and CXCL10 that we previously have shown to be increased 192 after stimulation of the innate cells of vitiligo patients by DAMPs or PAMPs [3]. We also 193 measured the levels of CXCL16 that is produced by keratinocytes and mediates CD8+ T cell 194 skin trafficking under oxidative stress in vitiligo patients [13]. The 7 patients with increased 195 mitochondrial DNA in lesional sites had a significantly increased levels of IFN $\gamma$, CXCL9 and 196 CXCL16 $(\mathrm{P}<0.05)$ in their serum compared to the patients without elevated mitochondrial DNA 197 (Figure 4E). The corresponding levels of CXCL-10 in the serum were of borderline significance $198 \quad(P=0.064)$. 
medRxiv preprint doi: https://doi.org/10.1101/2020.07.29.20163469; this version posted July 30, 2020. The copyright holder for this preprint (which was not certified by peer review) is the author/funder, who has granted medRxiv a license to display the preprint in perpetuity.

\section{DISCUSSION}

202 Gut, and to a lesser extent, skin dysbioses have been reported in many inflammatory and 203 autoimmune disorders. Surprisingly, microbiome studies in vitiligo remain limited. Here we 204 have shown, for the first time, dysbiosis in the gut and skin microbiota of vitiligo subjects compared to controls. The most striking differences were detected in the deep dermis layer of the lesional skin where enrichment of pathogenic Tenericutes bacteria and a loss of protective

207 Bifidobacterium were associated with mitochondrial damage at the same site as well as 208 increased stress and immune activation markers in their peripheral blood. We do acknowledge 209 the relative limited number of subjects analysed being a potential weakness of this study. It is 210 important to state that this was an invasive study requiring six samples per patient (2 skin 211 biopsies, 2 skin swabs, stool and a blood sample). Moreover, the group numbers were based on recent human microbiome studies using the similar sequencing approach $[9,14-17]$.

214 We detected reduced $\alpha$-diversity (richness and distribution of bacterial species) in the stool of 215 vitiligo compared to controls with increased abundance of Firmicutes and reduced 216 Bacteroidetes. The ratio between Firmicutes and Bacteroidetes (F/B) was significantly higher 217 for vitiligo patients. A similar increase in the F/B ratio has previously been reported in other 218 autoimmune diseases such as type I diabetes, Grave's disease, lupus and multiple sclerosis 219 as well as autoimmune skin conditions including scleroderma and psoriasis [18]. Interestingly, 220 a protective effect of Bacteroides was recently reported in the gut of a mouse vitiligo model 221 and was associated with skin depigmentation of mice [10]. If the same protection holds true 222 for human vitiligo, reduction and/or lack of protective Bacteroides in the human gut may 223 contribute to disease onset or exacerbation. It is important to note that vitiligo depigmentation 224 is associated with better prognosis in melanoma patients [19] and interestingly, our stool 225 microbiota results in vitiligo patients (high F/B ratio) have striking similarities with good 226 responders in melanoma patients treated with anti-PD1 [20]. Together, these results 227 demonstrate differences in gut microbial composition between vitiligo and healthy controls and 228 may suggest a possible gut-skin axis in this disease. 
medRxiv preprint doi: https://doi.org/10.1101/2020.07.29.20163469; this version posted July 30, 2020. The copyright holder for this preprint (which was not certified by peer review) is the author/funder, who has granted medRxiv a license to display the preprint in perpetuity. All rights reserved. No reuse allowed without permission.

229 Our results analyzing skin microbiota emphasize a marked difference in the skin microbiota

230 when analyzed using swab versus biopsy sampling suggesting that there are several bacterial

231 genera that correlates strongly and significantly with the sample collection method. Most of the

232 studies to date that assessed the microbiota in skin disorders have used only swab samples.

233 The unique aspect of our study is that we obtained stool, skin swab and skin biopsy samples

234 from the same individuals thereby reducing inter-patient variability and strengthening

235 robustness of our study. Our results are in agreement with those of Prast-Nielsen [7] and

236 emphasize the need for simultaneous collection of swab (surface) and biopsy (deep skin)

237 samples as biopsies are providing additional information which is critical in correct

238 interpretation of the data. Using swab samples, we found some albeit small differences and

239 trends in differential abundance of microbial composition between healthy and vitiligo skin

240 swabs; the largest differences seen in depletion of commensal Staphylococcus and

241 Acinetobacter and enrichment of pathogenic Paracoccus (Proteobacteria) in lesional skin.

242 Staphylococcus epidermidis is a known important symbiont in the skin which directly interacts

243 with cutaneous immune cells to regulate skin homeostasis [21]. Staphylococcus spp are also

244 known to colonise lesions in a number of dermatological diseases including atopic dermatitis

245 and presents propensity to form biofilms; adhesive surface-attached colonies that become

246 highly resistant to antibiotics and immune responses [22].

248 Current understanding of the skin microbiota is based on swab sampling the outermost layer 249 of the epidermis. Despite the invasive nature of biopsies, sampling dermal microbiota has 250 become critically important as the dermal community is less affected by external factors [8].

251 Our results give us, for the first time, a comprehensive profiling of the microbial species that 252 are depleted in full thickness subepidermal compartments of the vitiligo skin which may be 253 targeted for therapy. Thus, in contrast to the swabs, marked differences were found in microbial 254 community in lesional skin biopsies compared to non-lesional skin biopsies or healthy controls 255 with a decreased Actinobacteria and increased Firmicutes. Interestingly, the same imbalance 256 between Actinobacteria and Firmicutes in lesional versus non-lesional skin was found in the 
medRxiv preprint doi: https://doi.org/10.1101/2020.07.29.20163469; this version posted July 30, 2020. The copyright holder for this preprint (which was not certified by peer review) is the author/funder, who has granted medRxiv a license to display the preprint in perpetuity. All rights reserved. No reuse allowed without permission.

only other study that assessed skin microbiota in vitiligo skin [9]. However, in our cohort, the largest difference was the increase in Tenericutes and mitochondrial DNA in biopsies from lesional skin. With such 'black-and-white' results even with the limited number of subjects, it is tempting to speculate that Tenericutes may be used as a marker phylum for patients that may benefit from a supplementation of probiotics or bacterial lysates with bifidobacteria in addition to established treatment. Further analyses and interventional studies with bifidobacteria supplementation are required to confirm this hypothesis.

The latest evidence in the literature emphasizes the interaction between mitochondria and microbiota [23] 19. It has been recently shown that the mitochondrial genotype modulates both reactive oxygen species (ROS) production and the species diversity of the gut microbiome [24]. Interestingly, mitochondrial alterations with increased production of ROS have been reported in vitiligo cells $[25,26]$. Our results are in accordance with these in vitro studies and demonstrate potent mitochondrial damage in lesional skin of patients. As observed in the gut of mice [24], $\alpha$-diversity decreased in samples with high mitochondrial DNA. Modification of the microbiome only in the biopsy samples having mitochondrial DNA strongly argues in favor of microbiome modification induced by the mitochondrial stress. Interestingly, the genus that was almost completely absent in the 7 patients with the mitochondrial DNA in the skin is Bifidobacterium which is well-known to have protective effects and to decrease the activation of innate immune cells [27]. Moreover, those 7 patients had also a significantly increased levels of IFN $\gamma$, CXCL9, CXCL10 and CXCL16 in their serum compared to the patients without elevated mitochondrial DNA. Thus, we can hypothesize that similarly to what has been shown in the gut of mice [24], primitive mitochondrial stress in some vitiligo patients could be responsible for the change in the skin microbiome. This skin dysbiosis could then trigger the innate response through PAMPs and lead to the production of IFN $\gamma$ and chemokines that can be detected in the serum of these patients. Of course, this hypothesis needs to be confirmed 
medRxiv preprint doi: https://doi.org/10.1101/2020.07.29.20163469; this version posted July 30, 2020. The copyright holder for this preprint (which was not certified by peer review) is the author/funder, who has granted medRxiv a license to display the preprint in perpetuity.

283 in larger number of patients and ideally metagenomics should be performed to characterize

284 the origin of mitochondrial DNA.

285 There are a number of unique aspects to this study. First and foremost it is its novelty. To our

286 knowledge, there are no data examining the role of microbiota in vitiligo skin compared to

287 healthy skin. Secondly, there are matched multiple samplings (swab, biopsy, stool, serum)

288 from each patient avoiding inter-patient variability and thereby allowing for robustness of the

289 data even with a relatively limited sample size. Our key data demonstrating differences

290 between skin swabs and skin biopsy microbiota and between lesional compared to non-

291 lesional or control skin are all highly significant $(\mathrm{P}<0.001)$ suggesting important biological

292 differences between these sites. Thirdly, we have demonstrated the skin dysbiosis in vitiligo

293 patients is associated with profound mitochondrial damage and loss of protective bacteria at

294 the same site with heightened innate immune response in the blood of vitiligo patients

295 compared to healthy controls. These novel data not only describes vitiligo-specific cutaneous

296 and gut microbiota, but it also shows, for the first time in humans, a link between mitochondrial

297 alteration, microbiota and innate immunity. This opens up new avenues to explore in potential

298 treatment of vitiligo and other auto-immune disorders. 
medRxiv preprint doi: https://doi.org/10.1101/2020.07.29.20163469; this version posted July 30, 2020. The copyright holder for this preprint (which was not certified by peer review) is the author/funder, who has granted medRxiv a license to display the preprint in perpetuity.

\section{MATERIALS AND METHODS}

300 Biological samples

301 Twenty (20) subjects were recruited for this study (Table 1). Ten vitiligo patients with stable 302 disease and 10 healthy patients were recruited from the Department of Dermatology, Archet 2 303 Hospital, CHU Nice, after informed, written consent was obtained. Exclusion criteria included 304 presence of other autoimmune diseases or prior treatment (phototherapy, topical or systemic 305 corticosteroids, systemic antibiotics and/or other immunosuppressive agents) for up to 3 306 months before skin sampling. The groups were matched for gender, age, and biopsy location. 307 All skin samples were taken from the dry locations (Table 1). Swab and biopsy samples were 308 collected at the same time for each patient. From each vitiligo patient, we obtained two 4-mm 309 skin punch biopsies (1 from lesional, $L$ and 1 from non-lesional, NL site) and from each healthy patient 1 skin biopsy of the same size. Skin swabs were taken at the same time from adjacent 311 skin area sampling $5 \mathrm{~cm} \times 5 \mathrm{~cm} \mathrm{~L}$ and NL skin sites using sterile dry swabs (Copan Diagnostics) 312 and rinsed in $200 \mu \mathrm{l}$ sterile $0.15 \mathrm{M} \mathrm{NaCl}$ and $0.1 \%$ Tween20 (v/v). The same morning, stool 313 samples as well as $10 \mathrm{~mL}$ of blood was also collected from all subjects. Serum was obtained 314 from the blood following Ficoll gradient centrifugation (Lymphoprep®, Euromedex, France). All 315 biological samples ( $n=60$ from vitiligo patients and $n=40$ from healthy controls) were stored at $316-80^{\circ} \mathrm{C}$ until analysis. The study was approved by the National Ethics Committee (N14.028) 317 and was carried out in accordance with The Code of Ethics of the World Medical Association 318 (Declaration of Helsinki).

DNA isolation from stool samples

321 Eighty to $120 \mathrm{mg}$ of frozen stool was transferred to Precellys soil grinding SK38 lysing tubes 322 (Bertin Technologies, Montigny-le-Bretonneux, France) and one volume of warm $\left(37^{\circ} \mathrm{C}\right)$ lysis 323 buffer [4\% (w/v) SDS, $50 \mathrm{mM}$ TrisHCl pH 8.0, $500 \mathrm{mM} \mathrm{NaCl}, 50 \mathrm{mM}$ EDTA] was added.

324 Samples were homogenized for 10 mins at room temperature using a Vortex adapter. 325 Lysozyme (Sigma Aldrich Chemie $\mathrm{GmbH}$, Germany; final concentration $6.25 \mathrm{mg} / \mathrm{ml}$ ) was 326 added and samples were incubated at $37^{\circ} \mathrm{C}$ for $30 \mathrm{~min}$, then transferred to $80^{\circ} \mathrm{C}$ heating block 
medRxiv preprint doi: https://doi.org/10.1101/2020.07.29.20163469; this version posted July 30, 2020. The copyright holder for this preprint (which was not certified by peer review) is the author/funder, who has granted medRxiv a license to display the preprint in perpetuity.

327 and incubated for 15 mins by inverting every 5 mins. Samples were then centrifuged at $4^{\circ} \mathrm{C}$

$32820,000 \mathrm{~g}$ for 5 mins and supernatants were collected; proteinase K (Roche Diagnostics GmbH,

329 Germany) was added (final concentration $0.4 \mathrm{mg} / \mathrm{ml}$ ) and the samples were incubated on a

330 heating block at $70^{\circ} \mathrm{C}$ for 10 mins. After incubation, $10 \mathrm{M} \mathrm{NH}_{4} \mathrm{OAc}$ (final concentration $2 \mathrm{M}$ )

331 was added and samples were incubated on ice for 5 mins, then centrifuged at $4^{\circ} \mathrm{C} 20,000 \mathrm{~g}$

332 for 10 mins. Supernatants were collected and an equal volume of cold isopropanol was added.

333 The samples were stored on ice for 30 mins and thereafter centrifuged at $4^{\circ} \mathrm{C} 20,000 \mathrm{~g}$ for 20

334 mins. Pellets were washed 2-3 times with cold $70 \%$ ethanol, dried and dissolved overnight in

335 commercial Tris-EDTA buffer (1xTE). The following day, the DNA concentrations were

336 measured using Qubit dsDNA Broad Range Assay kit (Thermo Fisher Scientific Inc., USA) on

337 Qubit 3.0 fluorometer (Thermo Fisher Scientific Inc., USA). RNAse (Thermo Scientific, 338 Lithuania) at final concentration of $1 \mu \mathrm{g} / \mu \mathrm{l}$.

DNA isolation from skin samples

341 Bacterial DNA was extracted from skin biopsies and swabs using QIAamp ${ }^{\circledR}$ DNA Microbiome 342 Kit (Cat. No. 51704) (QIAGEN GmbH, 40724 Hilden, Germany). We followed manufacturer's 343 protocol with a single modification. After addition of Proteinase $\mathrm{K}$ the second time, samples 344 were incubated overnight on a heating block at $56^{\circ} \mathrm{C}$. After eluting DNA, the concentrations were measured using Qubitтм 1X dsDNA HS Assay Kit (Life Technologies Corporation, Oregon

346 97402, USA) on Qubit 4.0 fluorometer (Thermo Fisher Scientific Inc., USA).

$16 S$ rRNA Gene Library Preparation and Amplicon Sequencing

349 The sequencing library was prepared according to Earth Microbiome Project's Protocol [28] 350 with the following modifications. The fused primers were modified to contain barcode sequence 351 on both forward $(341 \mathrm{~F})$ and reverse $(805 \mathrm{R})$ primers and selected to target the V3-V4 region 352 instead of the V4 region. Sequences of fused primers are provided as Supplementary Table

353 8. The PCR reactions for library preparation were carried out in triplicates as follows: 20 ng of 354 template DNA was mixed with 5PRIME HotMasterMix (Quantabio, USA) consisting of: 1U Taq 
medRxiv preprint doi: https://doi.org/10.1101/2020.07.29.20163469; this version posted July 30, 2020. The copyright holder for this preprint (which was not certified by peer review) is the author/funder, who has granted medRxiv a license to display the preprint in perpetuity.

polymerase, $45 \mathrm{nM} \mathrm{Cl}, 2.5 \mathrm{mM} \mathrm{Mg2}+, 0.2 \mathrm{mM}$ of each dNTP, $0.2 \mu \mathrm{M}$ of each primer (Eurofins Genomics, Germany) and $0.64 \mathrm{ng}$ bovine serum albumin (BSA) in a final volume of $25 \mu \mathrm{l} p e r$ reaction. The PCR conditions were: $90^{\circ} \mathrm{C}$ for $15 \mathrm{~s}$ and $94^{\circ} \mathrm{C}$ for 3 mins followed by 35 cycles of $94^{\circ} \mathrm{C}$ for $45 \mathrm{~s}, 50^{\circ} \mathrm{C}$ for $1 \mathrm{~min}$ and $72^{\circ} \mathrm{C}$ for $1.5 \mathrm{mins}$, after which a final elongation step at $72^{\circ} \mathrm{C}$ for 10 mins was performed. The triplicates were pooled and visualized on $1 \%$ agarose gel to estimate the size of the amplicons. DNA concentrations of the amplicons were measured as described in the section above. Every PCR run includeed a negative (water) and a positive (MOCK community sample) control. The following reagent was obtained through the $\mathrm{NIH}$

363 Biodefense and Emerging Infections Research Resources Repository, NIAID, NIH as part of 364 the Human Microbiome Project: Genomic DNA from Microbial Mock Community B (Even, Low Concentration), v5.1L, for 16S RNA Gene Sequencing, HM-782D. Libraries were then pooled in equimolar concentrations and the amplicon pool was purified according to protocol using AMPure XP beads (Beckman Coulter, USA). Prior to amplicon sequencing the amplicon pool was diluted in $10 \mathrm{mM}$ Tris- $\mathrm{HCl}(\mathrm{pH} 8.5)$ to a final concentration of $5 \mathrm{nM}$. Following the Illumina recommendations, the amplicon pool was denaturated using an equal amount of $0.2 \mathrm{M} \mathrm{NaOH}$ (BioUltra) (Sigma Aldrich Chemie $\mathrm{GmbH}$, Germany) and further diluted to $12 \mathrm{pM}$ in

371 hybridization buffer (HT1 buffer included in the Reagents Kit v3, Illumina, USA). The pool was 372 finally spiked with 5\% denaturated PhiX control library (Illumina, USA). The sequencing was performed using the MiSeq sequencing platform with the Reagents Kit v3, 600 cycles (Illumina,

374 USA).

Microbiome Analyses: Composition, Diversity and Discovery of Metagenomic Biomarkers

377 The composition and diversity of the gut microbiome were assessed using QIIME2 [29]. 378 Initially, read-pairs were demultiplexed using deML [30] before sequences were quality filtered 379 and denoised using DADA2 [31]. For stool samples, total sequencing yield was $1,595,147$ 380 reads with median of $74,594(n=21)$. For skin samples $7,499,237$ reads was a total yield 381 distributed among 73 samples, with median of 96,497. Raw sequence data were 382 demultiplexed and quality filtered using the q2-demux plugin followed by denoising with 
medRxiv preprint doi: https://doi.org/10.1101/2020.07.29.20163469; this version posted July 30, 2020. The copyright holder for this preprint (which was not certified by peer review) is the author/funder, who has granted medRxiv a license to display the preprint in perpetuity. All rights reserved. No reuse allowed without permission.

383 DADA2 [31]. All amplicon sequence variants (ASVs) were aligned with mafft [32] and used to 384 construct a phylogeny with fasttree2 [33]. $\alpha$-diversity metrics (observed OTUs, Shannon index 385 and Faith's Phylogenetic Diversity [34]) and $\beta$-diversity metrics (unweighted UniFrac) [35] and 386 also Principle Coordinate Analysis [PCoA]) were estimated after samples were rarefied to 1000 387 sequences per sample. Shannon index accounts for both richness (number of species) and 388 distribution (how evenly the species are distributed) while Faith's PD pertains more to 389 phylogenetic diversity in a sample. $\beta$-diversity measures differences in microbial composition between different samples. Taxonomy was assigned to ASVs using the q2-feature-classifier 391 [36] classify-sklearn naïve Bayes taxonomy classifier against the SILVA full-length 99\% OTUs reference sequences [37].

395 IFN $\gamma$, CXCL9 and CXCL10 were measured from the serum using commercially available 396 ELISA kits (Peprotech, NJ, USA) while CXCL16 ELISA was purchased from R\&D Systems 397 (Minnesota, USA).

Statistical analyses

400 Differences in $\alpha$ - and $\beta$-diversity between groups were calculated using Kruskal-Wallis test ( $p$ 401 value is FDR adjusted) and PERMANOVA (number of permutations=999), respectively. We have used ANCOM [38] to investigate differentially abundant bacteria between the groups 403 ( $\mathrm{P}<0.05$, FDR adjusted for the analysis). Additionally, non-parametric independent sample t404 test (between controls and vitiligo subjects) and paired sample t-test (between lesional and non-lesional samples) were used. For all tests $\mathrm{P}<0.05$ was considered significant and $\mathrm{P}$ between 0.06 and 0.1 a trend. 
medRxiv preprint doi: https://doi.org/10.1101/2020.07.29.20163469; this version posted July 30, 2020. The copyright holder for this preprint (which was not certified by peer review) is the author/funder, who has granted medRxiv a license to display the preprint in perpetuity.

\section{ACKNOWLEDGEMENTS:}

411 We would like to thank Mona Svensson and Carina Lagerqvist for laboratory work, Emelie

412 Näslund Salomonsson for assistance with Illumina MiSeq run, as well as Sonia Amroune and

413 Raja Bahroumi for their assistance in clinic with patient recruitment. This work was supported by the Institut National de la Santé et de la Recherche Médicale (INSERM).

416 AUTHOR CONTRIBUTIONS:

417 HB was involved in sample collection and their processing, data analysis and interpretation, 418 as well as manuscript writing and construction of Figures. KSS along with CEW optimized the 419 protocol for extraction of DNA from skin biopsies. KSS performed DNA extractions, 16S 420 sequencing, statistical analysis and construction of Figures. KSS, SR and CEW provided 421 intellectual input, expertise and feedback on manuscript draft. AK performed all swab and 422 biopsy collections from vitiligo patients. TP was involved in patient recruitment. MKT performed 423 all the ELISA measurements. MKT and TP conceived the experiments, obtained financial 424 support, supervised the study, were involved in data interpretation and together wrote the 425 manuscript. All authors have read and approved the final version of the paper.

\section{CONFLICT OF INTEREST:}

428 The authors have no conflict of interest. This work was supported by a grant from ISISPharma. 429 The funding source had no involvement in study design, collection, analysis or interpretation 430 of the data or in writing of this manuscript.

DATA AVAILABILITY:

433 Sequence data have been deposited to the Sequence Read Archive (SRA) under accession 434 number PRJNA639425. All other data that support the findings of this study are available from 435 the corresponding authors upon reasonable request. 
medRxiv preprint doi: https://doi.org/10.1101/2020.07.29.20163469; this version posted July 30, 2020. The copyright holder for this preprint (which was not certified by peer review) is the author/funder, who has granted medRxiv a license to display the preprint in perpetuity.

\section{REFERENCES}

439 1. Roberts GHL, Santorico SA, Spritz RA. The genetic architecture of vitiligo. Pigment Cell Melanoma Res. 2020; 33:8-15.

2. Jin Y, Santorico SA, Spritz RA. Pediatric to Adult Shift in Vitiligo Onset Suggests Altered Environmental Triggering. J Invest Dermatol. 2020; 140:241-243.

3. Tulic MK, Cevazza E, Cheli Y, Jacquel A, Luci C, Cardot-Leccia $\mathrm{N}$ et al., Innate lymphocyte-induced CXCR3B-mediated melanocyte apoptosis is a potential initiator of T-cell autoreactivity in vitiligo. Nature Comm. 2019; 10:2178.

4. O'Neill AM, Gallo RL. Host-microbiome interactions and recent progress into understanding the biology of acne vulgaris. Microbiome. 2018; 6:177.

5. Stehlikova Z, Kostovcik M, Kostovcikova K, Kverka M, Juzlova K, Rob F et al. Dysbiosis of Skin Microbiota in Psoriatic Patients: Co-occurrence of Fungal and Bacterial Communities. Front Microbiol. 2019; 10:438.

6. Williams MR, Gallo RL. Evidence that Human Skin Microbiome Dysbiosis Promotes Atopic Dermatitis. J Invest Dermatol. 2017; 137:2460-2461.

7. Prast-Nielsen S, Tobin AM, Adamzik K, Powels A, Hugerth LW, Sweeney C et al. Investigation of the skin microbiome: swabs vs. biopsies. B J Dermatol. 2019; 181:572579.

8. Bay L, Barnes CJ, Fritz BG, Thorsen J, Restrup MEM, Rasmussen L et al. Universal

9. Ganju P, Nagpal S, Mohammed MH, Nishal Kumar P, Pandey R, Natarajan VT et al. Microbial community profiling shows dysbiosis in the lesional skin of Vitiligo subjects. Sci Rep. 2016; 6:18761.

461 10. Dellacecca ER, Cosgrove C, Mukhatayev Z, Akhtar S, Engelhard VH, Rademaker AW et al. Antibiotics Drive Microbial Imbalance and Vitiligo Development in Mice. J Invest Dermatol. 2020 Mar;140(3): 676-687.e6. doi: 10.1016/j.jid.2019.08.435. 
medRxiv preprint doi: https://doi.org/10.1101/2020.07.29.20163469; this version posted July 30, 2020. The copyright holder for this preprint (which was not certified by peer review) is the author/funder, who has granted medRxiv a license to display the preprint in perpetuity.

464 11. Dagnelie MA, Corvec S, Saint-Jean M, Nguyen JM, Khammari A, Dreno B. Cutibacterium canes phylotypes diversity loss: a trigger for skin inflammatory process. J Eur Acad Dermatol Venereol. 2019 Dec;33(12):2340-2348. doi: 10.1111/jdv.15795. Epub 2019 Aug 20.

468 12. Rizzatti G, Lopetuso LR, Gibiino G, Binda C, Gasbarrini A. Proteobacteria: A Common

Factor in Human Diseases. Biomed Res Int. 2017;2017:9351507. doi: 10.1155/2017/9351507. Epub 2017 Nov 2.

13. Li S, Zhu G, Yang Y, Jian Z, Guo S, Dai W, et al. Oxidative stress drives CD8(+) T-cell skin trafficking in patients with vitiligo through CXCL16 upregulation by activating the

14. Nakatsuji T, Chiang HI, Jiang SB, Nagarajan H, Zengler K, Gallo RL. The microbiome unfolded protein response in keratinocytes. J Allergy Clin Immunol. 2017

15. Jakobsson HE, Abrahamsson TR, Jenmalm MC, Harris K, Quince C, Jernberg C et al. Decreased gut microbiota diversity, delayed Bacteroidetes colonisation and reduced Th1 responses in infants delivered by caesarean section. Gut. 2014; 63:559-566.

16. Fadlallah J, Sterlin D, Fieschi C, Parizot C, Dorgham K, Kafsi HE et al. Synergistic convergence of microbiota-specific systemic IgG and secretory IgA. J Allergy Clin Immuno. 2019;I 143:1575-1585.

17. Baurecht H, Ruhlemann MC, Rodrigues E, Thielking F, Harder I, Erkens AS et al. Epidermal lipid composition, barrier integrity, and eczematous inflammation are associated with skin microbiome configuration. J Allergy Clin Immunol. 2018; $141: 1668-1676$.

18. Opazo MC, Ortega-Rocha EM, Coronado-Arrazola I, Bonifaz LC, Boudin H, Neunlist $M$ et al. Intestinal microbiota influences non-intestinal related auto-immune diseases. Front Microbiol. 2018 Mar 12;9:432. doi: 10.3389/fmicb.2018.00432. eCollection 2018.

19. Teulings HE, Limpens J, Jansen SN, Zwinderman AH, Reitsma JB, Spuls PI et al. Vitiligo-like depigmentation in patients with stage III-IV melanoma receiving 
medRxiv preprint doi: https://doi.org/10.1101/2020.07.29.20163469; this version posted July 30, 2020. The copyright holder for this preprint (which was not certified by peer review) is the author/funder, who has granted medRxiv a license to display the preprint in perpetuity. All rights reserved. No reuse allowed without permission.

immunotherapy and its association with survival: a systematic review and metaanalysis. J Clin Oncol. 2015; 33:773-781.

494 20. Gopalakrishnan V, Spencer CN, Nezi L, Reuben A, Andrews MC, Karpinets TV, et al. Gut microbiome modulates response to anti-PD-1 immunotherapy in melanoma patients. Science. 2018; 359:97-103.

21. Leonel C, Sena IFG, Silva WN, Prazeres P, Fernandes GR, Mancha Agresti P et al. Staphylococcus epidermidis role in the skin microenvironment. J Cell Mol Med. 2019; 23:5949-5955.

22. Gonzalez T, Biagini Myers JM, Herr AB, Khurana Hershey GK. Staphylococcal Biofilms in Atopic Dermatitis. Curr Allergy Asthma Rep. 2017; 17(12):81.

23. Saint-Georges-Chaumet $\mathrm{Y}$, Edeas M. Microbiota-mitochondria inter-talk: consequence for microbiota-host interaction. Pathog Dis. 2016; 74:ftv096.

504 24. Yardeni T, Tanes CE, Bittinger K, Mattei LM, Schaefer PM, Singh LN et al. Host mitochondria influence gut microbiome diversity: A role for ROS. Sci Signal. 2019;

25. Sahoo A, Lee B, Boniface K, Seneschal J, Sahoo SK, Seki T et al. MicroRNA-211 Regulates Oxidative Phosphorylation and Energy Metabolism in Human Vitiligo. J

510 26. Dell'Anna ML, Ottaviani M, Kovacs D, Mirabilii S, Brown DA, Cota C et al. Energetic mitochondrial failing in vitiligo and possible rescue by cardiolipin. Sci Rep. 2017;

513 27. lacob S, lacob DG. Infectious Threats, the Intestinal Barrier, and Its Trojan Horse: Dysbiosis. Front Microbiol. 2019; 10:1676.

28. Gilbert JA, Jansson JK, Knight RI. The earth microbiome project: successes and aspirations. BMC Biol. 2014 Aug 22;12:69. doi: 10.1186/s12915-014-0069-1.

517 29. Bolyen E, Rideout JR, Dillon MR, Bokulich NA, Abnet CC, Al-Ghalith GA et al. 518 Reproducible, interactive, scalable and extensible microbiome data science using QIIME 2. Nat Biotechnol. 2019; 37:852-857. 
medRxiv preprint doi: https://doi.org/10.1101/2020.07.29.20163469; this version posted July 30, 2020. The copyright holder for this preprint (which was not certified by peer review) is the author/funder, who has granted medRxiv a license to display the preprint in perpetuity. All rights reserved. No reuse allowed without permission.

520 30. Renaud G, Stenzel U, Maricic T, Wiebe V, Kelso J. deML: robust demultiplexing of $521 \quad$ Illumina sequences using a likelihood-based approach. Bioinformatics. 2015; 31:770522772.

523 31. Callahan BJ, McMurdie PJ, Rosen MJ, Han AW, Johnson AJ, Holmes SP. DADA2: High-resolution sample inference from Illumina amplicon data. Nat Methods. 2016; 13:581-583.

526 32. Katoh K, Misawa K, Kuma K, Miyata T. MAFFT: a novel method for rapid multiple sequence alignment based on fast Fourier transform. Nucleic Acids Res. 2002;

33. Price MN, Dehal PS, Arkin AP. FastTree 2--approximately maximum-likelihood trees for large alignments. PloS One. 2010; 5:e9490.

531 34. Faith DP. The role of the phylogenetic diversity measure, PD, in bio-informatics: getting the definition right. Evol Bioinform Online. 2007; 2:277-283.

533 35. Lozupone C, Knight R. UniFrac: a new phylogenetic method for comparing microbial communities. Appl Environ Microbiol. 2005; 71:8228-8235.

36. Bokulich NA, Kaehler BD, Rideout JR, Dillon M, Bolyen E, Knight R et al. Optimizing taxonomic classification of marker-gene amplicon sequences with QIIME 2's q2feature-classifier plugin. Microbiome. 2018; 6:90.

538 37. Quast C, Pruesse E, Yilmaz P, Gerken J, Schweer T, Yarza P et al. The SILVA ribosomal RNA gene database project: improved data processing and web-based tools. Nucleic Acids Res. 2013; 41:D590-596.

541 38. Mandal S, Van Treuren W, White RA, Eggesbo M, Knight R, Peddada SD. Analysis of composition of microbiomes: a novel method for studying microbial composition. Microb Ecol Health Dis. 2015; 26:27663. 
medRxiv preprint doi: https://doi.org/10.1101/2020.07.29.20163469; this version posted July 30, 2020. The copyright holder for this preprint (which was not certified by peer review) is the author/funder, who has granted medRxiv a license to display the preprint in perpetuity.

548 TABLE 1. Patient Characteristics

549

Characteristics

Subjects ( $n$ )

Age (years), mean (SE)

Gender (male/female)

Mean disease duration (years)

Family history (\%)

Location of biopsy ( $n$ )
Healthy controls

10

$60.2(2.8)$

$4 / 6$
Shoulder (5), forearm (3), leg (1), ankle Forearm (5), leg (4), ankle (1)

Vitiligo

10

$51.5(3.9)$

$3 / 7$

$3.2(1.4-22)$

$2(20 \%)$

550 
medRxiv preprint doi: https://doi.org/10.1101/2020.07.29.20163469; this version posted July 30, 2020. The copyright holder for this preprint (which was not certified by peer review) is the author/funder, who has granted medRxiv a license to display the preprint in perpetuity.

A

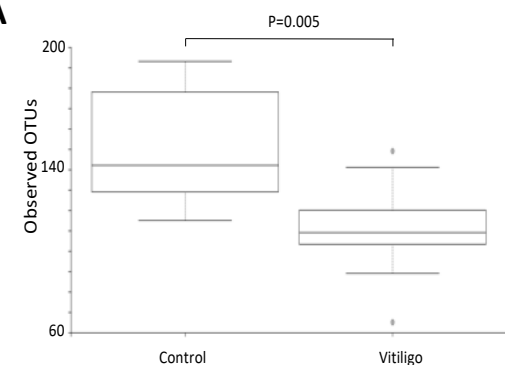

B

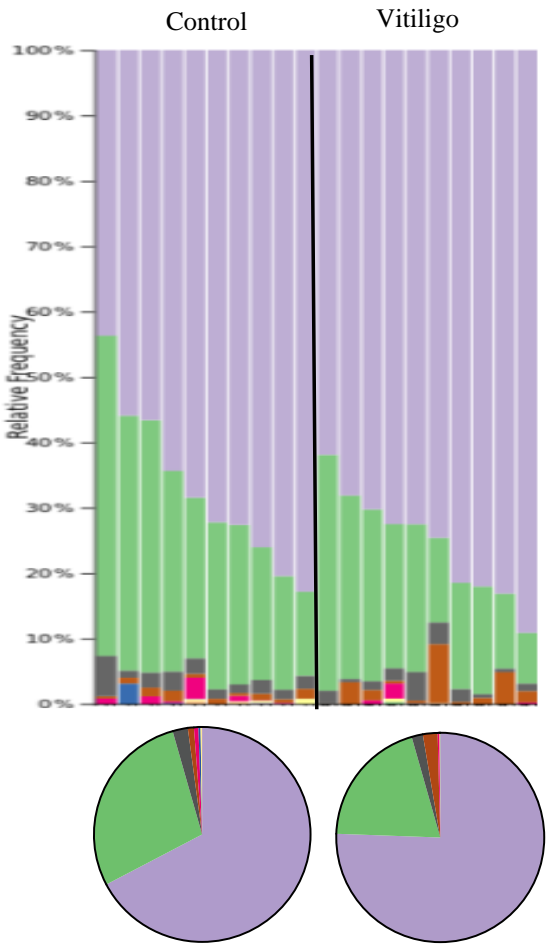

$P=0.115$

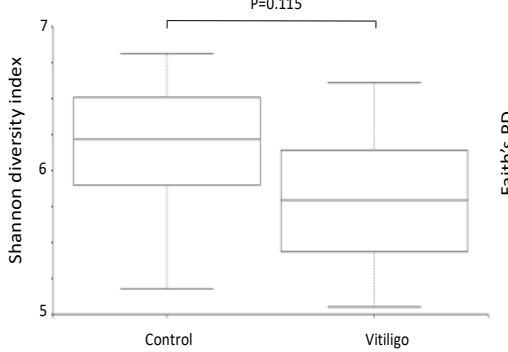

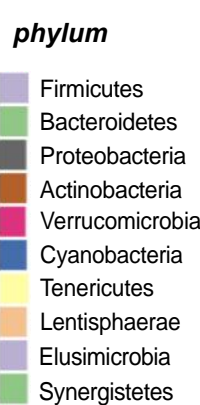

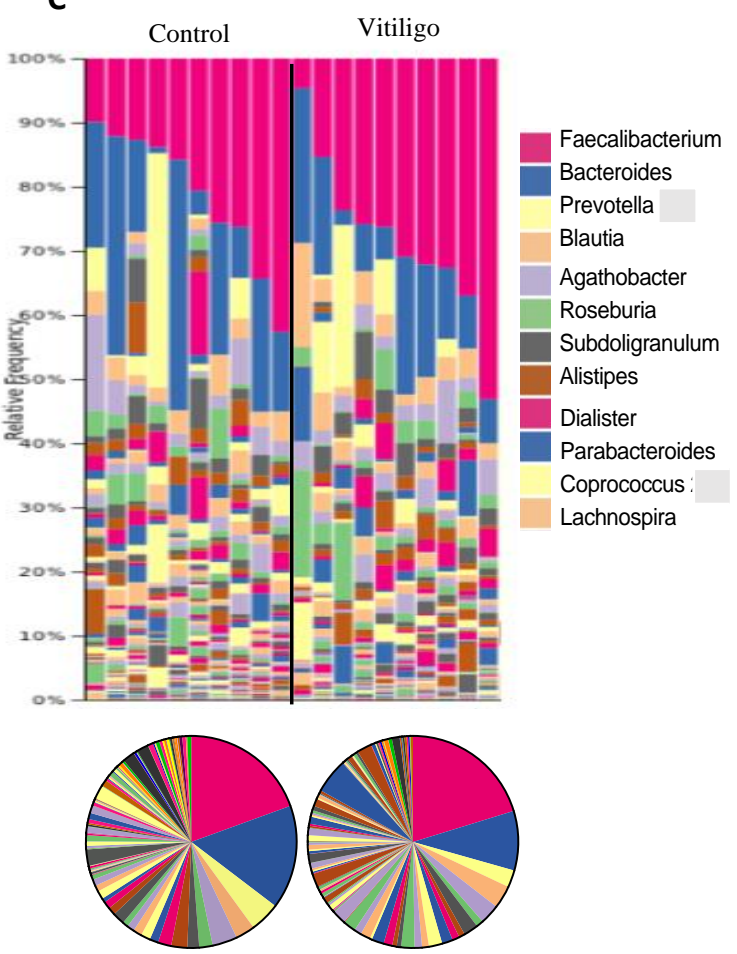

Figure 1 Reduced $\alpha$-diversity and increased Firmicutes/Bacteroides ratio in the gut microbiota of vitiligo subjects

555 (A) Boxplots illustrating the comparison of different measures of $\alpha$-diversity between healthy

$556(n=10)$ and vitiligo $(n=10)$ stool samples. (B) Bacterial composition and diversity expressed as

557 a percentage of relative abundance between the two groups at the phylum and (C) genus

558 levels. Individual subjects are shown as taxa bars (above) and grouped data as pie charts

559 (below). A complete list of OTUs is shown in Supplementary Table 1 and Table 2. 
medRxiv preprint doi: https://doi.org/10.1101/2020.07.29.20163469; this version posted July 30, 2020. The copyright holder for this preprint (which was not certified by peer review) is the author/funder, who has granted medRxiv a license to display the preprint in perpetuity.

A

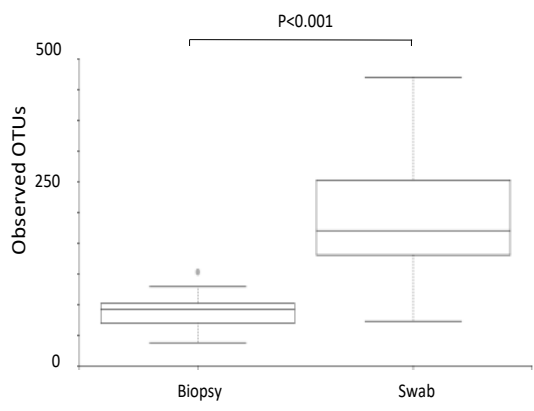

B

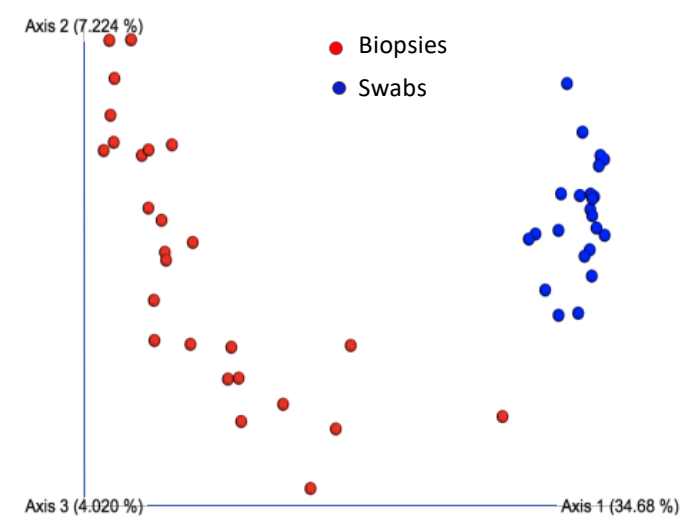

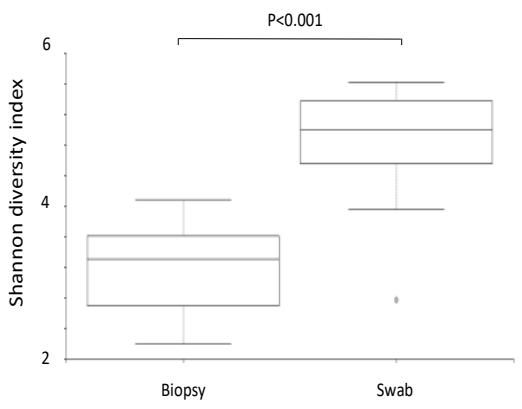

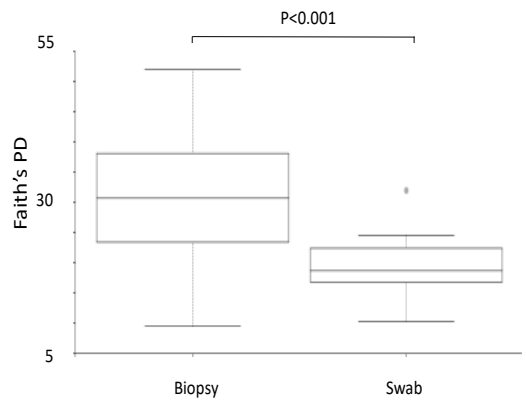

C

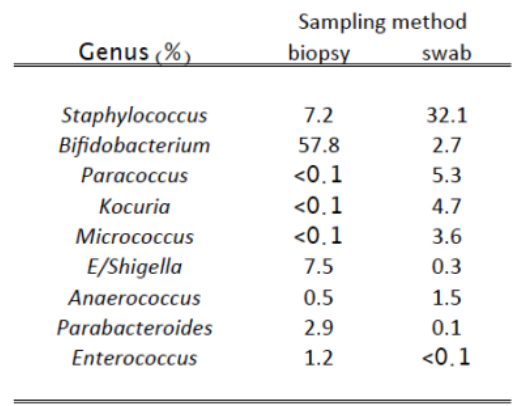

Figure 2 Difference in bacterial diversity and bacterial composition between swabs and biopsies due to sampling method

567 (A) Boxplots illustrating the comparison of different measures of $\alpha$-diversity in paired samples 568 of skin biopsies $(n=30)$ and skin swabs $(n=30)$. (B) PCoA plot representing $\beta$-diversity in 569 biopsies (red circles) and swabs (blue circles) $(p<0.001)$. (C) Demonstrates sampling-method 570 related differential bacterial abundance where bacteria enriched at each site is denoted and 571 given as a percentage of total genus. 
medRxiv preprint doi: https://doi.org/10.1101/2020.07.29.20163469; this version posted July 30, 2020. The copyright holder for this preprint (which was not certified by peer review) is the author/funder, who has granted medRxiv a license to display the preprint in perpetuity.

\section{A}
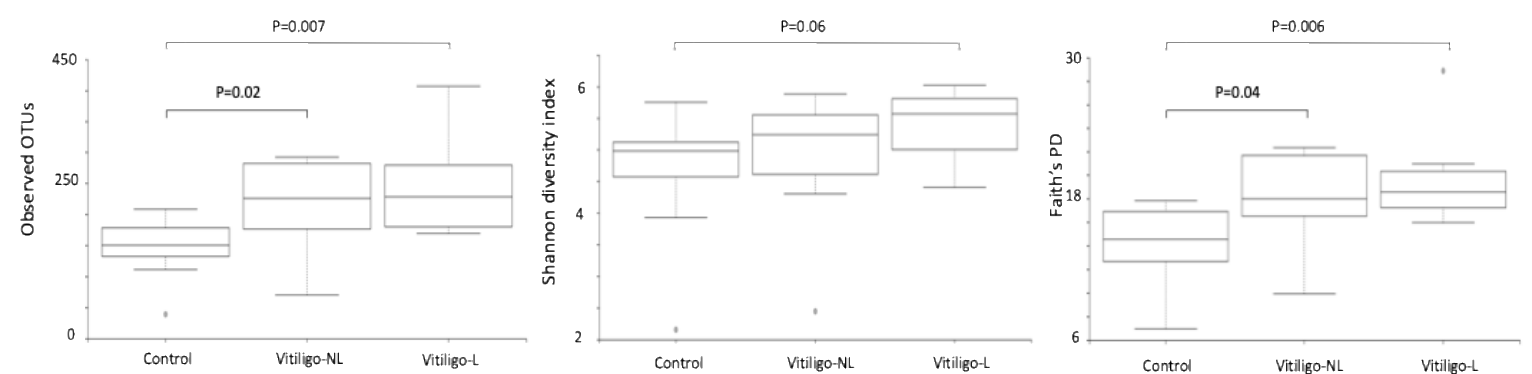

B

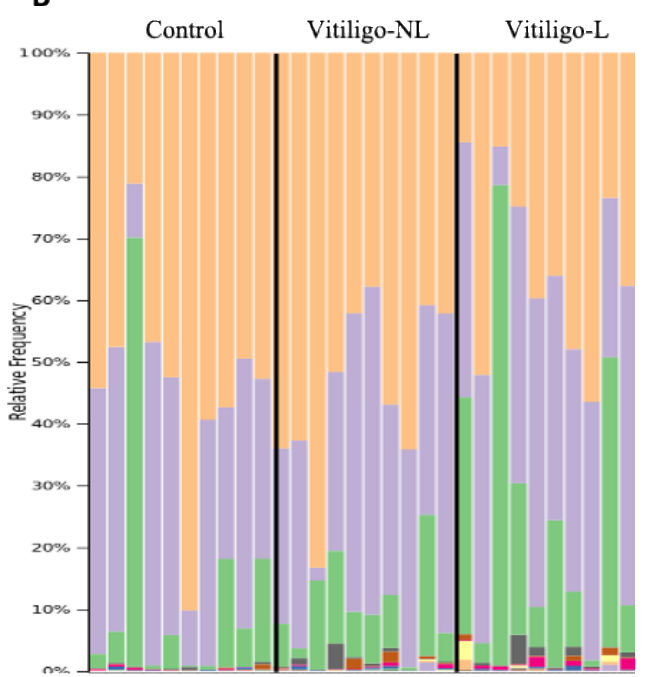

C
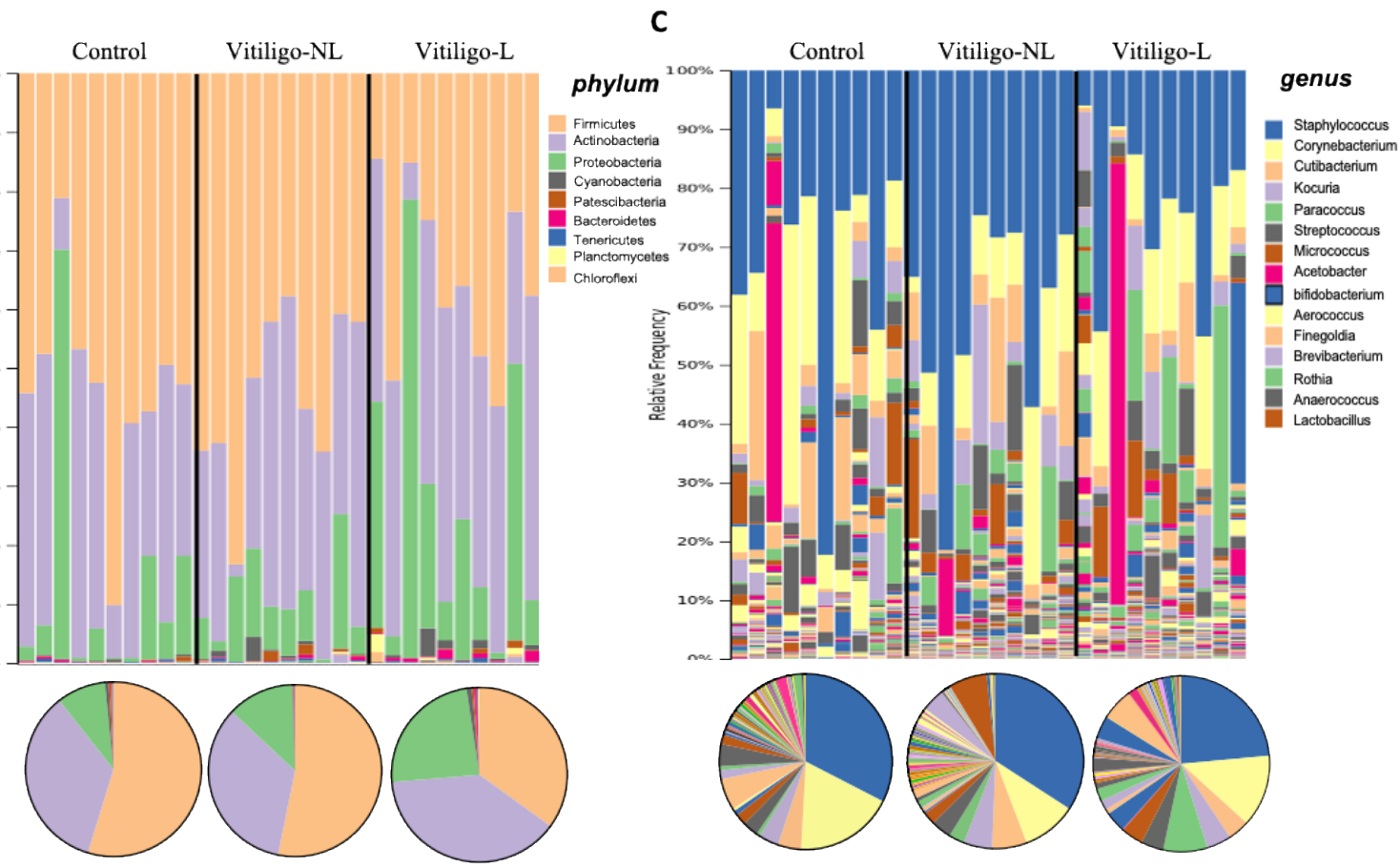

Figure 3 Higher $\alpha$-diversity, depletion of Staphylococcus and enrichment of Proteobacteria in

lesional swabs of vitiligo patients

582 (A) Boxplots illustrating the comparison of different measures of $\alpha$-diversity in skin swabs taken

583 from non-lesional $(N L)$ and lesional (L) regions of the skin from vitiligo patients $(n=10)$

584 compared to skin swabs taken from healthy controls $(n=10)$. (B) Bacterial composition and

585 diversity (expressed as percentage of relative abundance) between the groups are shown at

586 the phylum and (C) genus levels with individual taxa data shown above and grouped average

587 data as pie charts below. A complete list of OTUs is shown in Supplementary Table 3 and

588 Table 4. 
medRxiv preprint doi: https://doi.org/10.1101/2020.07.29.20163469; this version posted July 30, 2020. The copyright holder for this preprint (which was not certified by peer review) is the author/funder, who has granted medRxiv a license to display the preprint in perpetuity.
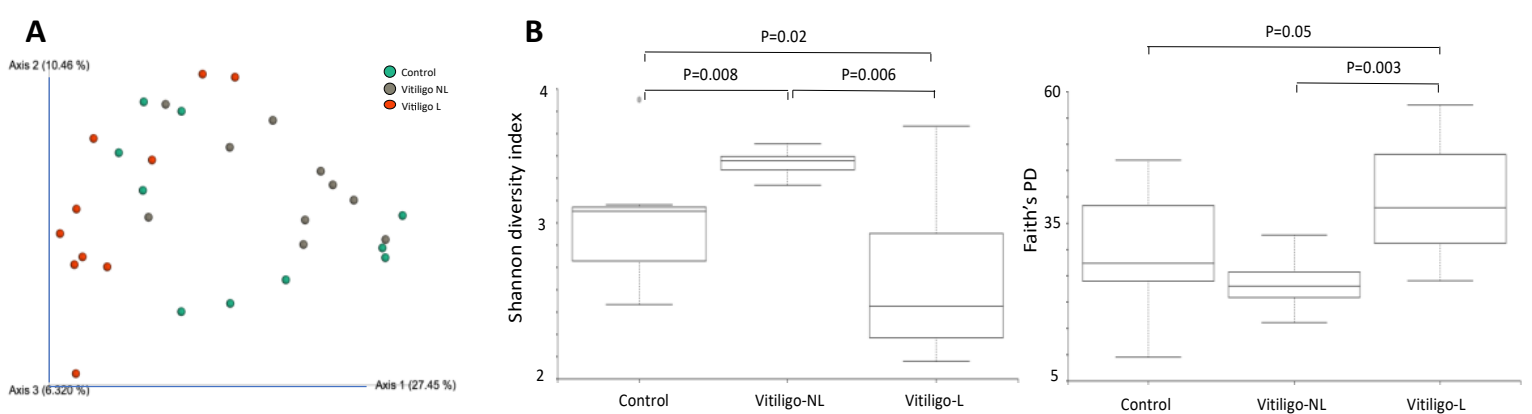

c

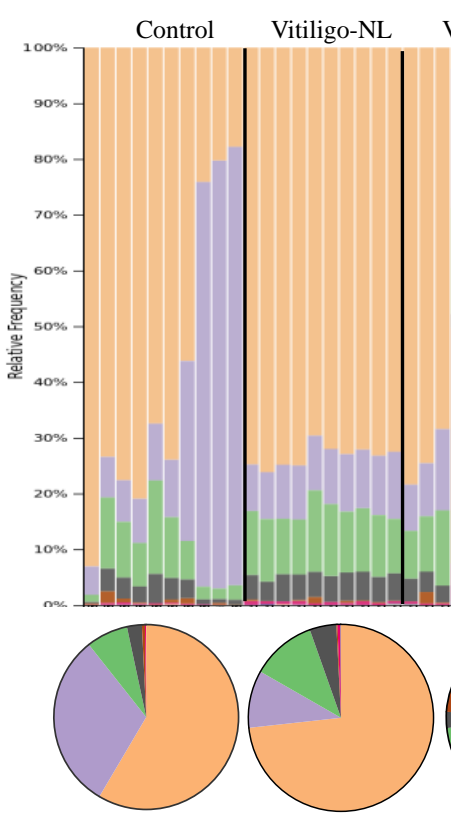

Vitiligo-L

D

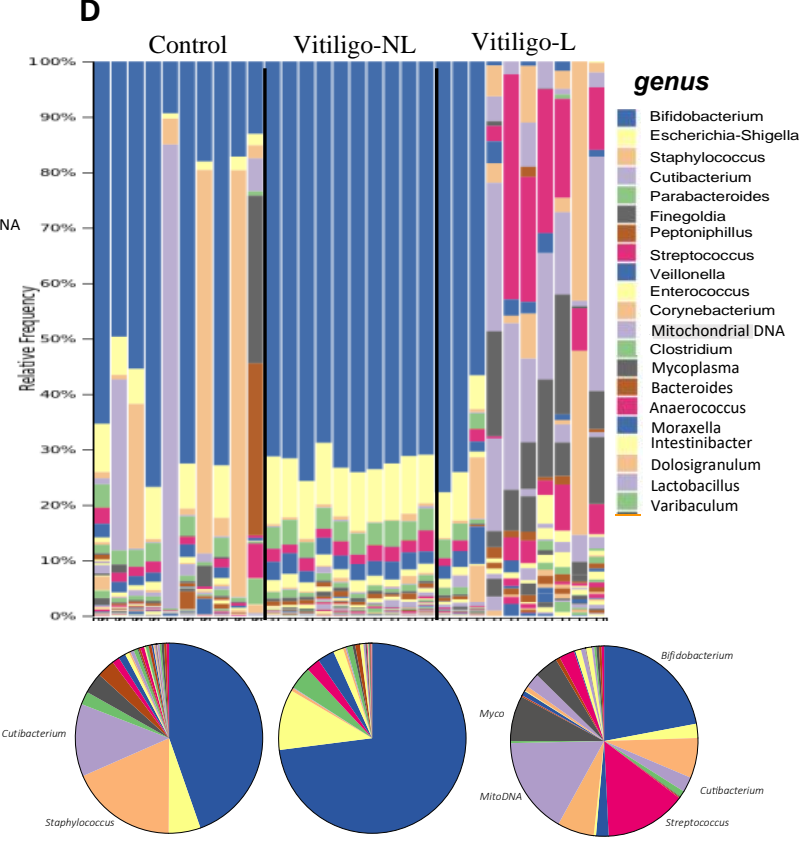

E
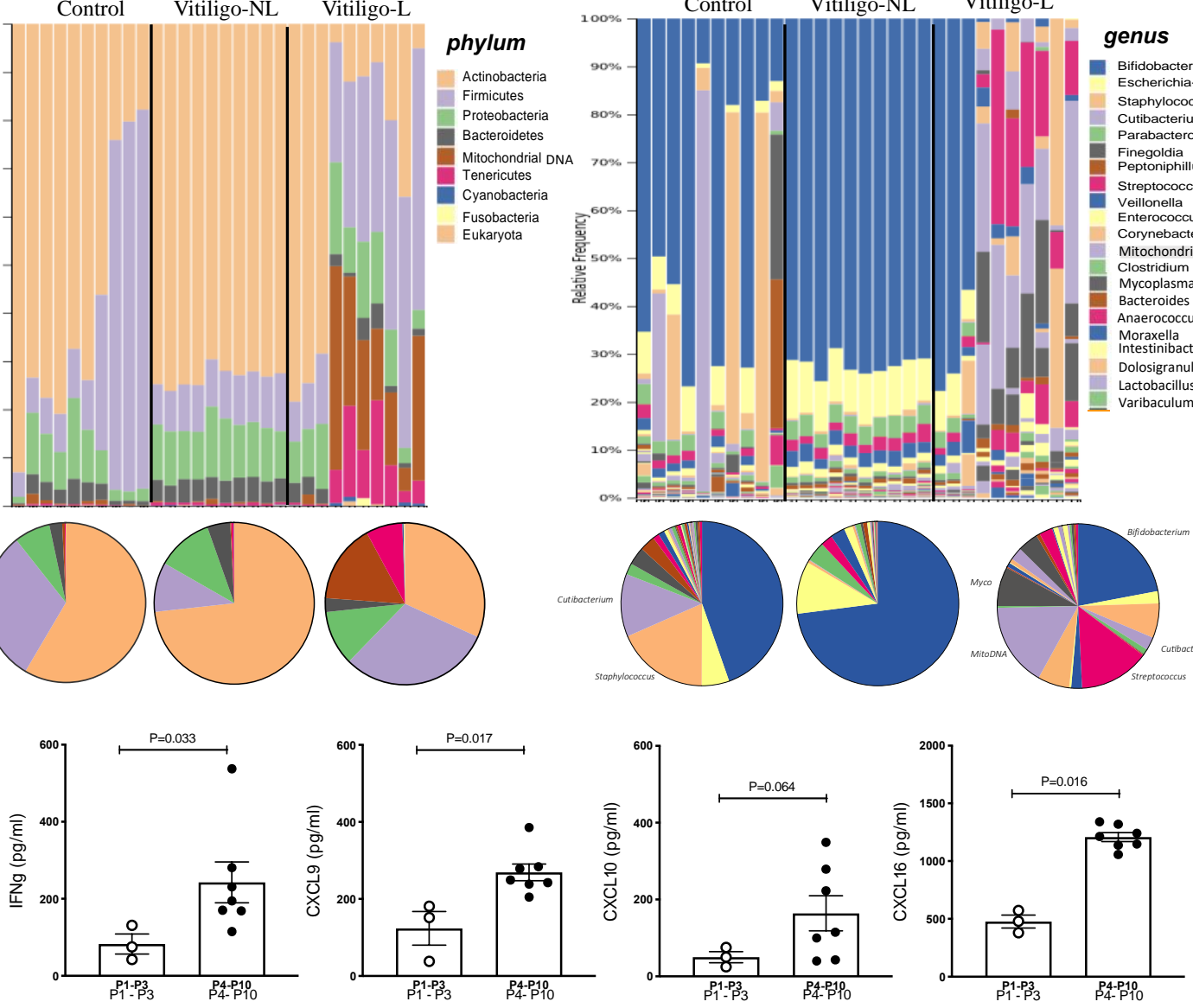

Figure 4 Lesional biopsies from vitiligo patients have distinct microbiota and are associated with changes in bacterial diversity, mitochondrial damage and activation of the innate immune

\section{4 system}

595 (A) PCoA plot representing beta diversity between the different groups illustrating biopsies

596 from the lesional zone of vitiligo patients (red circles) to be significantly different from all other

597 samples $(\mathrm{P}<0.001)$. (B) Boxplots illustrating the comparison of different measures of $\alpha$ -

598 diversity in skin biopsies taken from non-lesional $(N L)$ and lesional $(L)$ regions of the skin from 
medRxiv preprint doi: https://doi.org/10.1101/2020.07.29.20163469; this version posted July 30, 2020. The copyright holder for this preprint (which was not certified by peer review) is the author/funder, who has granted medRxiv a license to display the preprint in perpetuity. All rights reserved. No reuse allowed without permission.

599 vitiligo patients $(n=10)$ compared to skin biopsies taken from healthy controls $(n=10)$. (C) 600 Bacterial composition and diversity (expressed as percentage of relative abundance) between 601 the two groups at the phylum and genus (D) level. Individual subjects are shown as taxa bar 602 plots (above) and grouped data as pie charts (below). A complete list of OTUs is shown in 603 Supplementary Table 6 and Table 7. (E) Measurements of innate (IFN $\gamma$, CXCL9, CXCL10) and 604 stress marker (CXCL16) proteins in the serum of vitiligo patients with elevated mitochondrial 605 signature (patients 4-10 in C) compared to vitiligo patients without increased mitochondrial 606 signature (patients 1-3).

607

608

609

610

611

612

613

614

615

616

617

618

619

620

621

622

623

624

625

626 